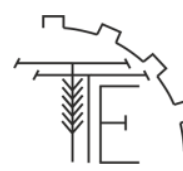

УДК 656.13.017: 629.3.004

DOI: 10.37128/2520-6168-2020-1-7

\title{
DETERMINATION OF ECONOMIC ADVISABLE DISTANCES OF AUTOMOBILE DELIVERY ON AUTOSERVICE ENTERPRISE
}

\author{
Mytko Mykola, $\mathrm{PhD}$, candidate of engineering sciences \\ Vinnytsia National Agrarian University
}

Митко Микола Васильович, кандидат технічних наук, Вінницький національний аграрний університет

In order to increase the efficiency of the operation of motor transport enterprises, the structure of production units for maintenance and repair of cars should be determined by the scope of work, taking into account the cost of implementation of the unit labor complexity of works. In case of inappropriateness of creating or maintaining an MTE of separate production units, maintenance and repairs of cars should be carried out at specialized service centers.

Therefore, with the improvement of production units of motor transport enterprises structure, it is important to provide economically expedient delivery distances for maintenance works and repair of cars by co-operation in car service companies, which provide relevant services.

The determination method of economically expedient distances of cars delivery and repair fund for car service companies is given. The cost of cars delivery and repair fund for $1 \mathrm{~km}$ to the car service companies or other motor transport enterprises (MTE), which accounts for 1 man-hour of labor-intensive maintenance and repair is determined.

The economically expedient delivery distances for maintenance and cars repair by cooperation in car service companies are determined. The results of the calculations show that for taxi-driven MTE economically appropriate in modern conditions of distance of delivery of cars to perform maintenance-1 and maintenance-2 are close to those recommended in literary sources. For truck and bus MTE the corresponding delivery distances for maintenance-1, maintenance-2 performance, ongoing repairs are significantly lower. When performing diagnostic works $D-1$ and $D-2$, most of the the district works of the ongoing repair, the economically reasonable distances of delivery to the car service companies are obtained that substantially exceed the recommendations given in the scientific literature.

Key words: cars, car service companies, centralized specialized production (CSP), cost of delivery, daily service $(D S)$, expedient delivery distances, maintenance, motor transport enterprises (MTE), ongoing repair $(O R)$.

F. 2. Table. 2. Ref. 14.

\section{Introduction}

In order to ensure competitiveness in the market of transport services, the ructure of production units of motor transport enterprises should be determined by the volume of maintenance and repair of vehicles, taking into account the cost of performing a unit of labor.

The following tasks were solved to achieve this:

- the main directions analysis of reforming the production infrastructure of motor transport;

- a mathematical model development for evaluating the performance of production units for maintenance and car repair;

- a methodology for determining the expedient of creating production units for the maintenance and cars repair in motor transport enterprises and related software development;

- research using the developed method of works performance efficiency with maintenance and cars repair in motor transport enterprises depending on the volume of works and capacity of production units;

- practical recommendations for improving the structure of maintenance production units and vehicles repair in motor transport enterprises development. Determination of economically expedient distances of cars delivery for performance of maintenance works and cars repair of motor transport enterprises in cooperation with the enterprises of car service. 


\section{Analysis of recent research and publications}

The normal production process course can proceed only in condition of continuous provision of its materials, tools, equipment, adjustment and equipment maintenance in a working condition, where the complex of these works constitutes the production infrastructure. Maintenance and repair is an essential part of the process maintenance and repair system in general, is regarded as ancillary, and includes functions to ensure the technical condition (readiness) and repair that must support the rolling stock of motor transport enterprises in a technically sound condition.

For the maintenance and cars repair it is necessary to have a certain complex of auxiliary services, or households: repair, instrumental, transport, delivery-warehouse, etc., which could satisfy the requirements for creation of separate production units of maintenance and repair of vehicles. Therefore, properly selected equipment and quality of work affect the repair efficiency.

Effective performance of many repair work types and maintenance of equipment using advanced technologies can be ensured by a widely developed system of scientific, industrial and other structures. Therefore, there is a need for continuous improvement of the household maintenance base, which creation, is an innovative project in Ukraine.

The changes taking place in this sector require reforms in the field of technical service. The proposed measures are aimed on repair development and maintenance base of the household, improvement of organization and technology of vehicles repair, the introduction of modern repair methods and organization of labor forms, which is not possible without the reconstruction of repair shops of the household [14].

Previous researches have identified the minimum amount of maintenance and vehicles repair, at which, it is advisable to perform specific types of work in motor transport enterprises and to create or maintain appropriate production units. Minimum volumes of work are established by comparing the cost of performing works on the maintenance and cars repair in a motor transport enterprise with the cost of performing these works in repair or car service enterprises $[5,6]$.

In case of separate production units absence in motor transport enterprises or inappropriateness of their creation or maintenance, car maintenance and repair work should be performed at specialized motor transport enterprises.

Therefore, it is important to determine the economically appropriate distances for delivery of vehicles or enterprise repair fund MTE, providing relevant maintenance and repair services.

Cited in the literature $[1,2]$ economically reasonable distances of cars delivery when performing maintenance work and cars repair by cooperatives, which were determined in the 70-80 years of the last century, do not meet the current conditions.

Currently, two opposite trends are affecting expedient delivery distances. On the one hand, there have been significant changes in the structure of road transport companies recently. The economically reasonable delivery distances given in $[1,2]$ were determined for motor transport enterprises that had from 100 to 300 vehicles $(63,4 \%$ of total MTE amount [2]). At present, the number of MTE with more than 100 cars is less than $1 \%$. The vast majority of motor transport enterprises (about $64 \%$ from total) have a rolling stock of up to 10 units. This leads to an increase of economically reasonable distance of car delivery.

On the other hand, over the specified period of time, the cost of fuel has increased in dollar terms by almost 6 times (from $\$ 0,15-0,25$ per liter in 70-80 years of the last century to $\$ 1,10-1,20$ per liter now). The part of cost of fuel oils materials in the cost cars delivery and repair fund in car service companies is now almost $40 \%$. This is where the cost of delivery increases and, accordingly, economically reasonable delivery distances performing maintenance and repair work of cars in cooperation with the motor transport enterprises reduction.

\section{The aim of the research}

The purpose of this work is to increase the efficiency of motor transport enterprises by improving the structure of production units for maintenance and cars repair.

\section{Key research results}

In order to ensure competitiveness in the market of transport services, the structure of production units of motor transport enterprises should be determined by the volume of maintenance and cars repair, taking into account the cost of performing a unit of labor. 


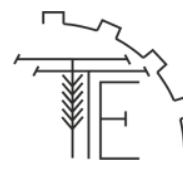

Vol. 108, No 1 / 2020

Economically appropriate distance of cars delivery and repair fund for the performance of the $i$-th type of maintenance and repair at the enterprises providing the relevant services is determined by the formula:

$$
R_{i}=\frac{\left(C_{M T E, 10, \mathrm{i}}-C_{C S P, \mathrm{i}}\right)}{\mathrm{C}_{d-1, k m, \mathrm{i}}},
$$

where $C_{M T E, 10, \mathrm{i}}$ - the cost of performing the $i$-th type of work at the MTE, which has 10 cars, uah/man-hour; $C_{C S P, \text { i }}$ - the cost of the norm-hour of performing $i$-th type of work on the CSP, uah/man-hour; $\mathrm{C}_{d-1 \mathrm{~km}, \mathrm{i}}$ - the cost of cars delivery to the CSP per $1 \mathrm{~km}$, which accounts for 1 person-hour of complexity, uah/man-hour $* \mathrm{~km}$.

Determining the cost of $1 \mathrm{~km}$ for CSP, which takes 1 person-hour of complexity $[4,5,6,7,8,9,11]$ :

$$
C_{d-1 \mathrm{~km}}=\left(C_{c a r}+S L_{d}+C_{f u e}+C_{\text {mar }}\right) / c_{\text {mar }},
$$

where $C_{c a r}$ - the cost of engaging the car when performing transportation, uah; $S L_{d}$ - drivers' salary, uah; $C_{\text {fue }}$ - fuel costs, uah; $C_{\text {mar }}$ - maintenance costs and cars repair, uah; $c_{m a r}-$ complexity of work at delivery on maintenance and cars repair, uah.

The cost of cars delivery and MTE repair fund to a car service company for $1 \mathrm{~km}$, which accounts for 1 person-hour of complexity, is shown in table 1 .

Table 1

The cost of cars delivery and MTE repair fund to a car service company for $1 \mathrm{~km}$, which accounts

\begin{tabular}{|c|c|c|c|c|c|c|}
\hline \multirow{3}{*}{$\begin{array}{l}\text { Name of works } \\
\text { on maintenance and repair }\end{array}$} & \multicolumn{6}{|c|}{$\begin{array}{l}\text { Delivery cost on } 1 \mathrm{~km} \text { to the service center, } \\
\text { uah / person-hour. }\end{array}$} \\
\hline & \multicolumn{2}{|c|}{ Taxomotors MTE } & \multicolumn{2}{|c|}{\begin{tabular}{|c|} 
Freight MTE \\
\end{tabular}} & \multicolumn{2}{|c|}{ Bus MTE } \\
\hline & $\begin{array}{l}\text { small class } \\
\text { cars } \\
\text { (Daewoo } \\
\text { Lanos) }\end{array}$ & $\begin{array}{l}\text { medium } \\
\text { class } \\
\text { cars } \\
\text { (GAZ- } \\
31105) \\
\end{array}$ & $\begin{array}{c}\text { low } \\
\text { lifting capacity cars } \\
\text { (GAZ-33021 } \\
\text { «GAZelle») }\end{array}$ & $\begin{array}{l}\text { especially weight } \\
\text { lifting capacity cars } \\
\text { (KAMAZ-53215) }\end{array}$ & \begin{tabular}{|c|} 
medium class buses \\
(Mercedes-Benz \\
«Vario» \\
TYP A407) \\
\end{tabular} & \begin{tabular}{|c|} 
big \\
class buses \\
(LAZ \\
A-183 D1 «LAZ \\
City») \\
\end{tabular} \\
\hline 1 & 2 & 3 & 4 & 5 & 6 & 7 \\
\hline Cleaning and washing & 15,39 & 20,45 & 23,84 & 19,83 & 25,47 & 21,84 \\
\hline General diagnosis (D-1) & 15,39 & 20,45 & 23,84 & 39,66 & 25,47 & 43,68 \\
\hline In-depth diagnosis (D-2) & 10,26 & 13,63 & 15,92 & 19,83 & 16,98 & 21,84 \\
\hline $\begin{array}{l}\text { Fastening, adjusting, } \\
\text { lubrication works } \\
\text { maintenance-1 }\end{array}$ & 7,70 & 8,18 & 9,53 & 4,96 & 3,40 & 4,85 \\
\hline $\begin{array}{l}\text { Fastening, adjusting, } \\
\text { lubrication works } \\
\text { maintenance-2 }\end{array}$ & 1,71 & 1,57 & 1,99 & 1,28 & 0,85 & 1,21 \\
\hline $\begin{array}{l}\text { Adjusting and collapsible } \\
\text { works } \\
\text { OR }\end{array}$ & 7,70 & 6,82 & 11,92 & 6,61 & 8,49 & 10,92 \\
\hline Coloring & 15,39 & 20,45 & 23,84 & 19,83 & 12,74 & 17,47 \\
\hline Aggregate & 3,08 & 4,09 & 4,77 & 6,61 & 5,09 & 7,28 \\
\hline $\begin{array}{l}\text { Locksmithing and } \\
\text { mechanical works }\end{array}$ & 3,08 & 4,09 & 4,77 & 6,61 & 5,09 & 7,28 \\
\hline Electrotechnical & 5,13 & 6,82 & 7,95 & 7,93 & 6,37 & 8,74 \\
\hline Rechargeable & 7,70 & 10,22 & 11,92 & 13,22 & 12,74 & 14,56 \\
\hline $\begin{array}{l}\text { Repair of power supply } \\
\text { devices }\end{array}$ & 5,13 & 6,82 & 7,95 & 7,93 & 6,37 & 8,74 \\
\hline Tire fitting and vulcanizing & 7,70 & 10,22 & 11,92 & 9,92 & 8,49 & 10,92 \\
\hline Blacksmith springs & 7,70 & 10,22 & 11,92 & 7,93 & 8,49 & 8,74 \\
\hline Copper & 7,70 & 10,22 & 11,92 & 9,92 & 8,49 & 10,92 \\
\hline Upholstery & 5,13 & 6,82 & 7,95 & 7,93 & 6,37 & 8,74 \\
\hline Taxomotors & 7,70 & 10,22 & - & - & - & - \\
\hline Wellding tin and armaturing & 5,13 & 6,82 & 7,95 & 9,92 & 6,37 & 10,92 \\
\hline
\end{tabular}
for 1 person-hour of complexity for maintenance and repair 


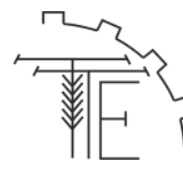

Vol. 108, No 1 / 2020

Economically appropriate for modern conditions of cars delivery distance, knots and units at performance of works on maintenance and repair by cooperation in specialized enterprises of conditions are shown in table 2.

Table 2

Economically appropriate for modern conditions of cars delivery distance, knots and units at performance of works on maintenance and repair by cooperation in specialized enterprises of conditions

\begin{tabular}{|c|c|c|c|c|c|c|}
\hline \multirow[b]{3}{*}{$\begin{array}{l}\text { Name of works } \\
\text { on maintenance and repair }\end{array}$} & \multicolumn{6}{|c|}{ Economically appropriate delivery distance, $\mathrm{km}$} \\
\hline & \multicolumn{2}{|c|}{ Taxomotors MTE } & \multicolumn{2}{|c|}{ Freight MTE } & \multicolumn{2}{|c|}{ Bus MTE } \\
\hline & $\begin{array}{l}\text { small class } \\
\text { cars (Daewoo } \\
\text { Lanos) }\end{array}$ & $\begin{array}{c}\text { medium } \\
\text { class } \\
\text { cars } \\
(\text { GAZ- } \\
31105) \\
\end{array}$ & $\begin{array}{c}\text { low } \\
\text { lifting capacity cars } \\
\text { (GAZ-33021 } \\
\text { «GAZelle») } \\
\end{array}$ & \begin{tabular}{|c|} 
especially weight \\
lifting capacity \\
cars \\
(KAMAZ- \\
53215) \\
\end{tabular} & \begin{tabular}{|c|} 
medium class \\
buses (Mercedes-Benz \\
«Vario» \\
TYP A407) \\
\end{tabular} & \begin{tabular}{|c|} 
big \\
class buses \\
(LAZ \\
A-183 D1 \\
«LAZ City») \\
\end{tabular} \\
\hline 1 & 2 & 3 & 4 & 5 & 6 & 7 \\
\hline Cleaning and washing & to 12 & to 7 & to 12 & to 7 & to 4 & to 4 \\
\hline General diagnosis (D-1) & to 170 & to 110 & to 100 & to 40 & to 100 & to 55 \\
\hline $\begin{array}{l}\text { In-depth diagnosis } \\
\text { (D-2) }\end{array}$ & to 200 & to 120 & to 170 & to 65 & to 150 & to 100 \\
\hline $\begin{array}{l}\text { Fastening, adjusting, } \\
\text { lubrication works } \\
\text { maintenance-1 }\end{array}$ & to 17 & to 15 & to 15 & 0 & to 3 & to 3 \\
\hline $\begin{array}{l}\text { Fastening, adjusting, } \\
\text { lubrication works } \\
\text { maintenance-2 }\end{array}$ & to 6 & to 2 & to 8 & 0 & to 10 & to 8 \\
\hline $\begin{array}{l}\text { Adjusting and collapsible } \\
\text { works OR }\end{array}$ & to 95 & to 60 & to 130 & to 80 & to 130 & to 95 \\
\hline Coloring & \multicolumn{6}{|c|}{ to 75} \\
\hline Aggregate & \multicolumn{6}{|c|}{ to 160} \\
\hline $\begin{array}{l}\text { Locksmithing and } \\
\text { mechanical works }\end{array}$ & \multicolumn{6}{|c|}{ to 180} \\
\hline Electrotechnical & \multicolumn{6}{|c|}{ to 370} \\
\hline Rechargeable & \multicolumn{6}{|c|}{ to 235} \\
\hline $\begin{array}{l}\text { Repair of power supply } \\
\text { devices }\end{array}$ & \multicolumn{6}{|c|}{ to 365} \\
\hline Tire fitting and vulcanizing & \multicolumn{6}{|c|}{ to 225} \\
\hline Blacksmith springs & \multicolumn{6}{|c|}{ to 340} \\
\hline Copper & \multicolumn{6}{|c|}{ to 1050} \\
\hline Upholstery & to 280 & & 190 & - & - & - \\
\hline Taxomotors & to 85 & & to 15 & to 4 & to 65 & to 40 \\
\hline
\end{tabular}

It is considered that when performing post work on maintenance and repair (daily service, maintenance-1, maintenance-2, diagnostic work, post work ongoing repairs (OR), coloring work OR, wellding tin and armaturing work OR) on centralized specialized enterprises (CSE) delivered directly by car. When performing ongoing works OR (aggregate, electrotechnical and other works) repair fund delivery on CSP is carried out by a low lifting capacity truck (GAZ-33021 «GAZelle»).

Obtained economically appropriate delivery distances for maintenance and work repair of cooperative vehicles are significantly different from those reported in the scientific literature. So, according to the works $[1,2]$ economically appropriate cars delivery radius when performing cooperative works are for maintenance $-1-9 \ldots 15 \mathrm{~km}$, for maintenance $-2-20 \ldots 45 \mathrm{~km}$, for work OR $-40 \ldots 80 \mathrm{~km}$.

According to Table 2, for taxomotors and freight MTE, the economically viable distance for OR is up to $12 \mathrm{~km}$, then for bus MTE - up to $4 \mathrm{~km}$.

If it is economically appropriate for a taxomotor transport enterprises in modern conditions, the cars delivery distances for maintenance- 1 and maintenance- 2 performance are close to those recommended in the literature, then, for freight and bus companies, the corresponding delivery distances are significantly smaller. This also applies to the cars distance delivery to the car service companies for the execution of ongoing 


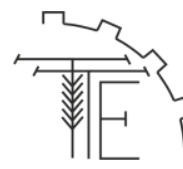

works OR (regulatory and assembly work OR). For these works, the delivery distances shown in Table 2 substantially limit the ability to perform these works by cooperating with car service companies. That is, for maintenanc-1, maintenance-2, post work and ongoing repairs for small motor transport enterprises with up to 10 weightlifting capacity cars, it is advisable to have 1-2 working positions to perform these types of work.

Regarding the performance of D-1 and D-2 diagnostic work, most of the precinct ongoing repair works, then obtained economically appropriate delivery distances to the motor transport enterprises significantly exceed the recommendations given in the scientific literature [1,2]. This is due to the small amount of these works in small enterprises and the considerable cost of performing these works directly in the trucking companies. First of all, it is caused by the high cost of technological equipment, especially, diagnostic posts.

\section{Conclusion}

Improvement of production units of maintenance works and cars repair on motor transport enterprises depending on the volume of these works necessitates the transfer of a works part for execution in the car service enterprise. However, the possibility of cooperative works in motor transport enterprises limited by economically appropriate car delivery distances or a repair fund in the central specialized productions, who provide relevant services.

The method of determination of economically appropriate distances of car delivery and repair fund for motor transport companies is presented. The economically expedient delivery distances for maintenance and cars repair by cooperation in car service companies are determined.

Installed, for small MTE with up to 10 weightlifting capacity cars, for maintenanc-1, maintenance-2, post work and ongoing repairs (OR) it is advisable to have 1-2 working positions to perform these types of work.

Regarding the performance of D-1 and D-2 diagnostic work, most of the precinct ongoing repair and post works, then the specified works in small motor transport enterprises appropriate to perfume in cooperation with the motor transport enterprises, this is due to the small amount of these works in small enterprises and the considerable cost of performing these works directly in the trucking companies. Economically appropriate delivery distance for implementation indicated works make up from 75 to $370 \mathrm{~km}$.

\section{References}

[1] Kanarchuk, V. E., Kurnikov, I. P. (1997). Vyrobnychi systemy na transporti [Production systems for transport]. Kiev: Vyscha shkola. [in Ukrainian].

[2] Kuznetsov, E. S., Kournikov, I. P. (1988). Proizvodstvinaya baza avtomobilnogo transporta [Road transport production base]. M.: Transport. [in Russion].

[3] Mytko, M. V. (2016). Dotsilnist stvorenya vyrobnychyh pidrozdiliv z obslugovuvanya ta remontu avtomobiliv [Determination of the expedincy of production units' creation for the maintenance and repair of vehicles]. Visnyk Vinnytskogo politehnichnogo instytutu [Bulletin of the Vinnytsia Polytechnic Institute]. Vinnytsia: VNTU, 1(124), 138-141. [in Ukrainian].

[4] Mytko, M. V. (2018). Udoskonalenya struktury vyrobnychyh pidrozdiliv z obslugovuvanya ta remontu avtomobiliv [Improving the structure of manufacturers maintenance and repair services cars]. Visnyk Vinnytskogo politehnichnogo instytutu [Bulletin of the Vinnytsia Polytechnic Institute]. Vinnytsia: VNTU, 6(141), 104-110. [in Ukrainian].

[5] Mytko, M. V. (2019). Udoskonalenya struktury vyrobnychyh pidrozdiliv z obslugovuvanya ta remontu avtomobiliv [Improvement of the production units' structure for car maintenance and repair] (Extended abstract of Candidates thesis). Kyiv. [in Ukrainian].

[6] Mytko, M. V. (2019). Udoskonalenya struktury vyrobnychyh pidrozdiliv z obslugovuvanya ta remontu avtomobiliv [Improvement of the production units' structure for car maintenance and repair] (Candidate's thesis). Kyiv. [in Ukrainian].

[7] Savin, Y. F., Mytko, M. V. (2016). Dotsilnist stvorenya vyrobnychyh pidrozdiliv z obslugovuvanya ta remontu avtomobiliv [Expediency of creating production units of servicing and repair cars]. Visnyk Natsinalnogo transportnogo universitetu. Seria "Tehnichni nauky». Naukovo-tehnichnyi zbirnyk [Bulletin of the National Transport University. "Technical Sciences» Series. Scientific and Technical Collection]. Kyiv: NTU, 1(34), 424-429. [in Ukrainian].

[8] Savin, Y. F., Mytko, M. V. (2016). Methodyka vyznachenya dochilnosti stvorenya vyrobnychyh pidrozdiliv z obslugovuvanya ta remontu transportnyh zasobiv [Method for determining expediency of 
creating industrial divisions of servicing and repair of vehicles]. Suchasni tehnologii $v$ mashynobuduvani ta transporti. Naukoviy zurnal. - Lutsk: Lutsk NTU, 2(6), 130-138. [in Ukrainian]

[9] Savin, Y. H., Mytko, M. V., Romanuk, S. O. (2018). Rekomendatsii schodo dotsilnosti stvorenya vyrobnycchyh pidrozdiliv $\mathrm{z}$ obslugovuvanya ta remontu avtomobiliv [The recomendations for the expedient of the creation of the production subsections of servising and repairing of the transport vehicles]. Visnuk mashynobuduvanya ta transport. Naukovyi zurnal [Bulletin of mechanical engineering and transport. Scientific journal]. Vinnytsia: VNTU, 1(7), 92-101. [in Ukrainian]

[10] Savin, Y. H., Mytko, M. V. (2019). Metodychni osnovy udoskonalenya struktury vyrobnychyh pidrozdiliv avtotransportnyh pidpryemstv [Methodological bases for improving the structure of production subdivisions of motor vehicles enterprises]. Visnyk Natsinalnogo transportnogo universitetu. Seria "Tehnichni nauky». Naukovo-tehnichnyi zbirnyk [Bulletin of the National Transport University. «Technical Sciences» Series. Scientific and Technical Collection]. Kyiv: NTU, 1(43), 159 - 166. [in Ukrainian]

[11] Savin, Y. H., Mytko, M. V. (2019). Vyznachenya economichno dotsilnyh vidstaney dostavky avtomobilei na avtoservisnomu pidpryemstvi [Determination of economic advisable distances of automobile delivery on autoservice enterprise]. Visnyk Vinnytskogo politehnichnogo instytutu [Bulletin of the Vinnytsia Polytechnic Institute]. Vinnytsia: VNTU, 2(143), 99-104. [in Ukrainian].

[12] Andrusenko, S. I. (2009). Tehnologichne proektuvanua avtotransportnyh pidpryemstv: navch.posybnyk [Technological design of motor transport enterprises: teaching. Manual]. ed. S. I. Andrusenko. K.: Karavela. [in Ukrainian]

[13] Transportnoi strategii Ukrainy na period do 2020 roku. Shvaleno rosporyadzenyam KMY vid 20 zovtnya 2010 roku [Ukraine's transport strategy for the period up to 2020. Approved by the CMU Order of October 20, 2010]. № 2174-p. Rezym dostupu: hppt://zakon3.rada.gov.ua/laws/show/2174-2010. [in Ukrainian].

[14] Trukhanska, O. O. (2018). Pidvyschenya yakosti remontno-tehnichnogo obslugovyvanya silskogospodarskoi tehniky [Improving quality of repair and technical service of agricultural equipment]. Vseukrainskyi naukovo-tekhnichnyi zhurnal «Tekhnika, enerhetyka, transport APK», 3(102), 52-61. [in Ukrainian].

\section{ВИЗНАЧЕННЯ ЕКОНОМІЧНО ДОЦІЛЬНИХ ВІДСТАНЕЙ ДОСТАВКИ АВТОМОБІЛІВ НА ПІДПРИЕМСТВА АВТОСЕРВІСУ}

Для підвищення ефективності роботи автотранспортних підприсмств структура виробничих підрозділів з технічного обслуговування та ремонту автомобілів повинна визначатися обсягами робіт з врахуванням собівартості виконання одиниці трудомісткості робіт. У випадку недоиільності створення або утримання в автотранспортних підприємств окремих виробничих підрозділів, роботи з обслуговування і ремонту автомобілів повинні виконуватися на спеціалізованих підприємствах автосервісу.

Тому важливе значення при удосконаленні структури виробничих підрозділів автотранспортних підприємств мають економічно доцільні відстані доставки для виконання робіт з технічного обслуговування і ремонту автомобілів за кооперачією в підприємствах автосервісу, які надають відповідні послуги.

Наведено методику визначення економічно доцільних відстаней доставки автомобілів та ремонтного фонду на підприємства автосервісу. Визначено вартість доставки автомобілів та ремонтного фонду на $1 \mathrm{kм}$ в підприємства автосервісу або інші автотранспортні підприємства (АТП), яка припадає на 1 людино-годину трудомісткості робіт з технічного обслуговування (ТО) $i$ ремонту.

Визначені економічно доцільні відстані доставки для виконання робіт 3 технічного обслуговування і ремонту автомобілів за кооперацією в підприємствах автосервісу. Результати розрахунків свідчать, що для таксомоторного АТП економічно дочільні в сучасних умовах відстані доставки автомобілів для виконання ТO-1 i TO-2 близькі до рекомендусмих в літературних джерелах. Для вантажних $i$ автобусних автотранспортних підприємств відповідні відстані доставки для виконання ТО-1, ТО-2, постових робіт поточного ремонту (ПР) суттево менші. При виконанні діагностичних робіт Д-1 $і$ Д-2, більщості дільничних робіт поточного ремонту, отримані економічно дочільні відстані доставки в підприємства автосервісу суттєво перевищують рекомендації, наведені в науковій літературі. 


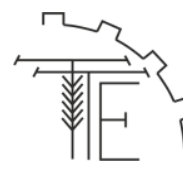
транспорт АПК

Ключові слова: автомобілі, автотранспортні підприємства (АТП), вартість доставки, доцільна відстань доставки, підприємства автосервісу, поточний ремонт (ПР), технічне обслуговування (ТО), цеентралізовано-спеціалізовані виробництва (ЦСВ), щзоденне обслуговування (ЦО).

Ф. 2. Табл. 2. Лім. 14.

\section{ОПРЕДЕЛЕНИЕ ЭКОНОМИЧЕСКИ ЦЕЛЕСООБРАЗНЫХ РАССТОЯНИЙ ДОСТАВКИ АВТОМОБИЛЕЙ НА ПРЕДПРИЯТИЯ АВТОСЕРВИСА}

Для повышения эффективности работы автотранспортных предприятий структура производственных подразделений по ТО и ремонту автомобилей должна определяться объемами работ с учетом себестоимости выполнения единицы трудоемкости работ. B случае нецелесообразности создания или содержания в АТП отдельных производственных подразделений, работы по обслуживанию и ремонту автомобилей должны выполняться на специиализированных предприятиях автосервиса.

Поэтому важное значение при совериенствовании структуры производственных подразделений автотранспортных предприятий имеют экономически целесообразные расстояния доставки для выполнения работ по техническому обслуживанию и ремонту автомобилей по кооперации на предприятиях автосервиса, которые предоставляют соответствующие услуги.

Приведена методика определения экономически целесообразных расстояний доставки автомобилей и ремонтного фонда на предприятия автосервиса. Определена стоимость доставки автомобилей и ремонтного фонда на 1 км на предприятия автосервиса или другие автотранспортные предприятия, приходящаяся на 1 человеко-час трудоемкости работ по техническому обслужсиванию (ТО) и ремонту.

Определены экономически целесообразные расстояния доставки для выполнения работ по техническому обслуживанию и ремонту автомобилей по кооперации на предприятиях автосервиса. Результаты расчетов показывают, что для таксомоторного АТП экономически целесообразные в современных условиях расстояния доставки автомобилей для выполнения ТО-1 и ТО-2 близки к рекомендуемым в литературных источниках. Для грузовых и автобусных АТП соответствующие расстояния доставки для выполнения ТО-1, ТО-2, постовых работ ПР существенно меньше. При выполнении диагностических работ Д-1 и Д-2, большинства участковых работ текущего ремонта, полученные экономически цчелесообразные расстояния доставки на предприятия автосервиса сущуественно превышают рекомендации, приведенные в научной литературе.

Ключевые слова: автомобили, автотранспортные предприятия (АТП), ежедневное обслуживание (ЕО), стоимость доставки, иелесообразна расстояние доставки, предприятия автосервиса, текущуий ремонт (ТР), техническое обслуживание (ТО), централизованоспециализированные производство (ЦСП).

Ф. 2. Табл. 2. Лит. 14.

\section{ВІДОМОСТІ ПРО АВТОРА}

Митко Микола Васильович - кандидат технічних наук, асистент кафедри «Технологічних процесів та обладнання переробних i харчових виробництв» Вінницького національного аграрного університету (вул. Сонячна, 3, м. Вінниця, 21008, Україна, e-mail: mytko_83@ukr.net.

Мытко Николай Васильевич - кандидат технических наук, ассистент кафедры «Технологических процессов и оборудования перерабатывающих и пищевих производств» Винницкого национального аграрного университета (ул. Солнечная, 3, г. Винница, 21008, Украина, e-mail: mytko_83@ukr.net.

Mytko Mykola - PhD, assistant of the Department of "Technological Processes and Equipment of Processing and Food Produchions" of Vinnitsia National Agrarian University (3, Solnechnaya, St, Vinnitsa, 21008, Ukraine, e-mail: mytko_83@ukr.net. 